\title{
But Why Do We Need Politicians? A Critical Review
}

Jack Corbett

School of International, Political \& Strategic Studies

ANU College of Asia \& the Pacific

Australian National University

Canberra ACT 0200

AUSTRALIA

jack.corbett@anu.edu.au

Tel: +61 261258394

Fax: +61 261255525

A slightly amended version of this paper is published in Policy Studies

Acknowledgements: I would like to thank David Marsh, John Boswell and participants at the University of Canberra's Governance Research Forum for comments on earlier versions of this paper. Any errors are of course my own. 


\section{But Why Do We Need Politicians? A Critical Review}

\section{Abstract}

In response to growing popular dissatisfaction with politics and politicians there has been a marked increase in academic work about anti-politics and depoliticization with numerous scholars seeking to defend politics by restating why it matters. However, these efforts have largely glossed over the related question of why politicians also matter. To fill this gap I propose a typology that captures how the different intellectual perspectives in this debate see the role of politicians - identifying six in particular: procedural, legitimacy, values, authority, persuasion and dissimulation. In doing so I review each contribution and highlight synergies and disagreements between them that in-turn reveal important insights and new lines of inquiry.

Keywords: demonization of politicians, anti-politics, depoliticization, democratic disillusionment, political leadership

\section{Introduction}

It has become accepted wisdom that popular faith in politicians has reached record lows. Aside from the frequent anecdotal reminders that newspaper columnists and talkback radio hosts provide, popular opinion polls consistently confirm that the public have a very low opinion of our political leaders (for discussion see Flinders, 2012a, pp. vii-x;Stoker, 2006, pp. 1-7; Hay, 2007, pp. 11-39; Evans, Stoker \& Nasir, 2013). According to this analysis, the conduct of politics and politicians are 'an unpleasant feature of modern life' with a significant proportion of citizens across Anglo-European countries agreeing that they should 'stop talking and take action', while a large minority believe that they would be served better if decisions were left to 'successful business people' or 'independent experts' (Evans, Stoker \& 
Nasir, 2013, p 11). The picture presented by this material is of an erosion of public trust in those who govern; possibly beyond repair or resuscitation.

In response to rising disillusionment with politics and associated debates about depoliticization, there has been a concerted attempt by some academics to defend politics and restate why it matters. There are a number of possible reasons why this task has largely fallen to the academy - a full discussion of which is beyond the scope of this article - including the fact that political actors who engage in apologetics gain little traction with voters and constituents. Certainly, praising politics and politicians rarely sells newsprint. However, despite some willingness to defend politics, with few exceptions the recent literature has not developed a forthright case for why we also need politicians. This is, I believe, a worrying oversight. As Peter Riddell (2010) asks, how can we defend politics without also defending politicians? Or, as David Easton (1965, p 212 \& 216) argued more dramatically, the history of regimes tells us that political systems in which the governed do not support or have confidence in those who occupy authority roles tend not to survive.

The stakes then, are high. In this article I take up this challenge to provide a case for why we need politicians by reviewing the recent literature on anti-politics. This is not a new question. Max Weber's (1978 [1922]) tripartite leadership model - traditional, legal rational and charismatic - is one of the most famous attempts to provide a theoretical justification for why modern government needs politicians but, in one way or another, since antiquity students of politics have reflected on why society needs leaders. In this article I am interested in contemporary rather than classical thinking. Specifically, I compare competing conceptualisations of why we need politicians that emerge from the literature concerned with anti-politics. I review how this body of work conceives of the different roles politicians should play and the normative standards used to assess whether they fulfil them. In doing so I create a typology (Table 1) of reasons for why we need politicians. What we learn from this 
exercise is that there is a great deal of diversity, even within this relatively small body of work, about why their function is important to democratic government. In turn, this recognition opens up new avenues of inquiry; both conceptual - there is an urgent need to link this recent literature to broader theoretical debates about why we need leaders and who they should be - and empirical - I conclude by outlining ways that further research might clarify some of the differences and coalesce around shared understandings that emerge from this work.

Let me make two important caveats before I begin. Firstly, this is an unwieldy literature and, as with all such reviews, deciding what to leave in and out is difficult. For the most part I have chosen to restrict discussion to what we might loosely call recent critical perspectives at the expense of the more mainstream literature (for example see Norris, 2011; Torcal and Montero, 2006; Dionne, 2004). The same disclaimer is relevant to how I have distinguished between literatures as the categorisations in Table 1 below are, I acknowledge, much more fluid in practice. Secondly, as outlined, a forthright articulation of why we need politicians is often absent from the contemporary anti-politics literature, so, for the most part, the discussion is driven by my interpretation of the implicit commitments each these scholars make about their value. Importantly, I acknowledge that each author has a different definition of politics (and anti-politics) that underpins their descriptive and normative stance, thus reinforcing my belief in the need to link these debates to broader theoretical discussions about the purpose of democratic leadership. Similarly, I acknowledge that there is a tension between the normative and descriptive aims of the studies I consider. However, I maintain that it is important to distinguish between the two, albeit acknowledging the endogenous limitations presented by any such attempt. 


\begin{tabular}{lll}
\hline \hline Rationale & Role & Normative Ideal \\
\hline Procedural & Parliamentarian & Deliberation \\
Legitimacy & Citizen-Legislator & Participation \\
Values & Steward & Honourable \\
Authority & Decision-Maker & Managerial \\
Persuasion & Advocate & Representation \\
Dissimulation & Thespian & Performative \\
\hline \hline
\end{tabular}

Having outlined some of the limitations let me explain what I see to be the advantages this typology brings to the current debate. The purpose of Table 1 and the ensuing discussion is to provide a degree of conceptual clarity to what is currently a disparate field. There is, as I will illustrate, a growing body of work that sees popular disenchantment with politicians as an observable and worrying trend. However, for the most part the difference between these attempts - why they think the demonization of politicians is a critical problem for democracy and what they consider to be the solution - is less clear. Weber saw the competition between leadership types as the engine room of social change (see Ascher 2013). Many of the authors discussed here would not go that far but do consider the actions of politicians to have some bearing on anti-political trends. As such, this classification, while not exhaustive or exclusive, goes some way ordering their reflections. Importantly, it reveals synergies and tensions between different types of analysis that can assist us in the creation of new lines of inquiry and associated research projects. To this end, the ensuing discussion is arranged so as to best illustrate how each strand of the debate seeks answers to questions that arise from other 
bodies of related work. In doing so it not only provides an important summary of state of the field, but also a roadmap for how this agenda can be pursued in the future.

\section{The Parliamentarian}

The procedural role that politicians play in a representative system is the most obvious place to start this discussion. A parliament has many functions, but debating and voting on legislation is central - it is the aspect of politics we explain first to high school students for example. Conversely, much is made of the hard work politicians make of this core task. In the public domain this critique predominantly concerns the nature of question time which is often seen to epitomise politicians behaving badly and illustrate that our political system is broken.

There have been numerous efforts to outline a blueprint for parliamentary reform - a full discussion of which is beyond the scope of this article. One of the most important is the version of decision-making principles and procedures advocated by deliberative democrats. This is a very diverse literature and I acknowledge that many of its key exponents would see little value in reforming current parliamentary systems, or, like Joshua Cohen $(1997 ; 1989)$, would see parliament as only one of many deliberative arenas. Moreover, deliberative democrats have tended not to be specifically interested in anti-politics; although their normative agenda is driven by a similar sense of disillusionment with the status quo. However, from the perspective of this discussion, I am interested in those scholars working in this tradition who see value in parliaments as deliberative forums and, by extension, consider politicians to be indispensable to the democratic process (Gutmann and Thompson, 2004; Uhr, 1998; Fung, 2004).

From this perspective, parliament can be a deliberative mechanism that turns political conflict into meaningful compromise and consensus, but its capacity to fulfil this role is distorted, 
either by moneyed or partisan interests, the short-termism encouraged by a twenty-four hour media cycle, or the temptations of executive domination. The ideal role for politicians, in this view, is defined primarily in terms of their function as parliamentarians who justify their decisions to the public by debating matters of common concern. Conversely, the demonisation of politicians largely stems from the perversion of this ideal in practice where reactive and poorly designed policy making produces sub-optimal outcomes that reflect the imperfect nature of deliberation.

The answer, in this view, is better - free, equal, open, justifiable, consensus orientated and dynamic (Gutmann and Thompson, 2004, p. 7) - deliberation, where informed, wellresourced and earnest citizens value diverse views, but remain committed to compromise and consensus. There is, I concede, much more to this critique than an advocacy of better procedures. As Gutman and Thompson (2004, p. 9) argue, deliberative democracy is also often based on a commitment to more participatory and inclusive decision-making. However, for the purposes of this discussion, the important claim is the instrumental one: that better policy outcomes flow from these improved processes, which ultimately result in increased respect for politicians:

If political deliberation tends to produce better decisions in the long run, and if political decision-makers in a democracy owe justifications to those who are bound by their decisions ... By deliberating with their fellow citizens, decision-makers can arrive at better, more adequately justifiable decisions and, in the process, express mutual respect among free and equal citizens (Gutmann and Thompson, 2004, p. 23).

\section{The Citizen-Legislator}

Related to the deliberative turn, advocates of more participatory forms of decision-making provide a distinctive argument as to why we need politicians that fits with their 'supply side' 
critique of contemporary democratic practice (Hay and Stoker, 2009). In his book Why Politics Matters, Gerry Stoker (2006) offers a series of explanations for why people have disengaged politically and proposes a number of solutions about how this problem could be rectified - the most important of which, from the perspective of this article, is tied to his belief in reviving a 'politics for amateurs'. Stoker acknowledges that the current democratic malaise is not caused by the flawed character of its leaders and, yet, ends up placing the corporatisation of decision-making and the professionalisation of politics in the dock politicians have become insulated from their constituents by party bureaucracies and, as a result, are victims of their own focus groups and spin machines. To take back politics and political institutions, and to promote 'politics for amateurs', he contends that we (the public) must have greater authority over policy-making via localised participatory modes of governance: we need to revive the notion of a citizen-legislator.

Politics is a place for amateurs, but we need to design institutions, structure processes and develop support systems so that amateurs can engage and improve their skills (Stoker, 2006, p. 150).

Like Stoker, Colin Hay (2007), in his book Why We Hate Politics, is largely concerned with the 'supply side' problems that face contemporary democracies. Echoing his constructivist approach, the power of ideas is central to his critique of public choice theory, neo-liberalism and a naive belief in globalisation, which he identifies as the primary culprits in contemporary democratic disenchantment. Like Stoker, Hay is somewhat sympathetic to the plight of politicians who, he claims, have been stripped of meaningful power by the neoliberal project and the associated pervasiveness of globalisation discourse. However, Hay also does not let them off scot-free. By succumbing to false neo-liberal promises, and marketised or technocratic solutions, he finds they are largely complicit in creating the gap between public expectations and their new powerlessness: 
So, are politicians themselves to blame? ... In projecting no less bleak, no less instrumental, and no less pessimistic assumptions about both their motivations and their capacity to act on to political actors and public servants, they have certainly conspired in the demonisation of the political. Moreover, informed by such assumptions, they have further denuded the political, discharging and off-loading their responsibilities to those less directly and publically accountable for their decisions. In so doing they have significantly undermined not only their capacity to deliver collective public goods, but also the collective societal capacity for public deliberation (Hay, 2007, p. 157).

Despite the subtle nuances that separate them, both Hay and Stoker retain a commitment to a more participatory form of politics. The assumption here is that we want to be more politically active, but are systematically discouraged from doing so. But, what if we don't want to participate? Conventional wisdom, Hibbing and Theiss-Morse (2002) argue in Stealth Democracy, assumes that a significant proportion of the population want greater input into political decisions and, yet, their survey material suggests the opposite: most people would much prefer to spend their time on non-political pursuits. Despite attempts to grapple with this problem (see Stoker, 2006, pp. 158-160; Evans, Stoker and Nasir, 2013), this remains a thorny question for advocates of this perspective.

\section{The Steward}

In contrast, the 'demand side' approach sees the growth of stealth views about democracy and the unwillingness of citizens to be more actively engaged in political activity as the root cause of contemporary anti-political sentiment. From this perspective, the cause of the problem (public antipathy towards politics and politicians) primarily lies with the consumers - the people. The most prominent example in this tradition is Robert Putnam's (2000) 'social 
capital' thesis. For Putnam, a variety of factors have fundamentally altered the nature of civic association since the 1960 s, ultimately begetting poor community life. This apathy, he argues, is cancerous to a democratic system that needs active and politically conscious citizens to generate the requisite trust and generalised reciprocity.

The most recent work in this tradition is Matthew Flinders' book (2012a) Defending Politics. While many of the scholars discussed here kick-off with Bernard Crick's (2000 [1962]) famous book In Defence of Politics, Flinders explicitly seeks to update this thesis - his book is published on the $50^{\text {th }}$ anniversary of the publication of Crick's book. Many of the root causes of the current 'bad faith model of politics' he identifies echo those outlined by Putnam and others (he includes chapters that defend politics against the market, denial, crisis and the media), but he makes a particular effort to highlight the danger of growing 'democratic decadents' or public apathy amongst the current generation who take these freedoms for granted - the vigour of the Arab spring is an obvious point of contrast (Flinders, 2012a, p. 160). In this respect, he sees himself as diametrically opposed to the position espoused by John Keane (2009) in the Life and Death of Democracy who welcomes the new era of 'monitory democracy' where citizens are increasingly sceptical of government. Rather than celebrating this shift, Flinders' book is infused with a strong sense of nostalgia for a post-war era, when, he argues, people appreciated community and democracy, and understood the dangers of totalitarianism and nationalism, as opposed to the complacency and parochialism of the internet generation:

The irony of this situation is that very few 'disaffected democrats', especially amongst the younger generation, who now appear so willing to turn their back on 'mere politics', have any direct experience of a real crisis (invasion, drought, famine, war, etc.) due to the security and stability provided to them by democratic politics (Flinders, 2012a, p. 125). 
In contrast to the two previous sets of literature that acknowledge we need politicians, but wish they were more deliberative or participatory, Flinders is the most vocal defender of current practice. Like Crick, his book is a veritable call to arms for those who believe in the value of politics. Political leadership, from this perspective, is a collective endeavour, but it is failing because the free riding public is not keeping up their end of the democratic bargain. For Flinders, it is too easy to blame politicians for the current malaise as they are labouring under the weight of our shared 'democratic decadence'. The point then is not that politicians, as stewards of our welfare, should act more honourably, but rather that they are honourable our mistrust is consistent with other forms of moral panic (Jones, 2008; Flinders, 2012b; Hatier 2012, Wood and Flinders, 2012) - we just fail to appreciate it:

... most politicians are actually just and only a few are just awful. Most politicians enter public life in order to make a positive difference to people's lives, their motivations are altruistic, and in making this choice they generally forgo the benefits of a permanent job and a higher salary while also accepting the significant pressure that holding political office places on an individual and his or her family (Flinders, 2012a, p. 3).

The answer to anti-politics from this perspective involves reviving respect (and even deference) for political leaders fostered by encouraging greater understanding of the promise and limits of politics (hence the book); a position which most scholars of politics who teach their discipline would have some sympathy. But, aside from advocating greater awareness of the practical limitations that constrain what politicians and democratic politics can and does achieve, Flinders doesn't really tell us much about what should be taught. It is one thing to argue that politics matters but questions about how it matters are much thornier.

The Decision-Maker 
Popular disillusionment with politics and politicians implicitly represents a challenge to contemporary forms of authority. Consequently, this article would not be complete without some reference to the way authority is defined and understood by the academy. Perversely, the anti-politics literature does not address this question in great detail - underscoring why making the conceptual link between the two bodies of work is important - and so to flesh out the typology I have had to cast the net further afield and the governance debate, which has become increasingly interested in depoliticization (see Fawcett and Marsh, forthcoming), is the most obvious entry point. However, I do acknowledge that this literature sits somewhat awkwardly within this article as there is an obvious overlap between the emphasis I place on authority in this section and the other viewpoints I summarise. I do not deny that all of the perspectives discussed here in some way or another make claims about the nature and purpose of authority - how it is constructed and how it should be exercised. I do believe, however, that these ideas coalesce here more than elsewhere and in doing so sharpen questions about why the decision-making function of politicians is particularly important.

Both strands of the governance debate revolve around a form of authoritative instrumentalism. In the Westminster tradition, the older core executive story, first employed as a move away from prime minister versus cabinet debates in British politics (Dunleavy and Rhodes, 1990; Elgie, 1995, 2011; Heffernan, 2003), sees political leaders, senior cabinet ministers and departmental heads as arbitrators between competing interests that are channelled via state-based institutions and their associated policy functions. Consequently, the challenge to executive authority by popular disenchantment with those who govern is primarily understood as a principle-agent dilemma: where state-based institutions are either unable or unwilling to implement government policies, or, due to poor coordination, competing interests and information asymmetry, policy actors undermine each other, usually via 'leaks'. From this perspective, the main solution involves increased executive authority, 
be it 'contingent and relational' (Rhodes, 2007, p. 1247) or structural, through hierarchy (managing the media cycle and less 'leaks'), and better government coordination (think phrases like 'whole-of-government' or 'joined up government'). Put simply, citizen concern with government performance is assuaged by improved policy implementation and better communication about what government has achieved (there are obvious similarities here with Pippa Norris' (2011) 'democratic deficit' argument). However, given that government, even in its now wider definition, is still primarily understood as a set of institutions, institutional reforms - whether they involve changes to accountability mechanisms, electoral systems or bureaucracies - are the main types of solutions promoted by advocates of this perspective.

The main alternative to both the Westminster or core executive description is the networked governance or differentiated polity model, most commonly associated with the work of Rod Rhodes $(1997,2007)$. From this perspective the shift from government to governance is characterised by dispersed power, with networks replacing hierarchies and markets - leading to the 'hollowing out' of the state. This change is characterised by increased complexity, with political actors involved in a variety of processes that are shaped by globalisation, devolution and the growing involvement of non-governmental organisations in all facets of political life. Politicians, in this view, remain influential, but, when compared with the core executive model, their authority has been undermined (Sørensen, 2006). Specifically, their role is less transformative as policy-making has become more about negotiation. In short, politicians have become 'managers' who shape the rules, form narratives and channel resources. And, while there is much more to this literature than the simplified distinction I have presented between how managerial politicians operate either through a core executive or a differentiated polity - advocates of metagovernance retain an interest in path dependency and hierarchical networks for example (for review see Marsh, 2011b; see also Jessop, 2004; Marsh et al., 2003; McAnulla, 2006) - from the perspective of this article the important point 
is that while we may disagree about the nature of the authority that politicians exercise, the fact that they have authority remains central to how we understand their function.

Running through this debate is a broader ontological and epistemological discussion. This is best illustrated by a brief account of Rhodes' move to interpretivism with Mark Bevir (2010), as outlined in their book The State as Cultural Practice. As opposed to the metagovernance story, often associated with critical realism, and core executive account, which is broadly institutionalist, they emphasise a decentred approach where actions are informed by the meanings and beliefs that individual actors hold within the context of governing traditions. In this view, the state and its authority is manufactured by the ideas actors hold about the world. These meanings, beliefs and traditions are not fixed, but are constantly being modified in response to new dilemmas - defined as arising when new perceptions come into conflict with existing beliefs (Rhodes and Bevir, 2010, p. 91). From this perspective popular disenchantment with elected representatives draws on a deeply embedded tradition of cynicism towards authority contained in the ideal of egalitarian democracy, which is simultaneously reinvented to accord with changing beliefs about the appropriate form of the contemporary state. The solution to anti-politics, in this view, requires the establishment of a plausible counter-narrative that challenges extant webs of belief and encourages actors to rethink the assumptions that underlie their perceptions (there is obviously a link here between this position and the Thespian discussion below).

\section{The Advocate}

Like their decision-making function, the case for why politicians as representatives is rarely put forcefully in the anti-politics litreature; deliberateive and participatory critiques, for example, engage with the idea but tend to focus on the distortion of the ideal rather than the function itself. Where it is considered it is usually as part of a broader sociological discussion 
about the politics of 'late modernity' and the changing nature of representation in contepmorary democracies. In this story, which begins with the new social movements of the 1960s and 1970s and ends with the shift from government to governance and a more 'personalised' and 'decoupled' polity of the $21^{\text {st }}$ century, the nature of represenation has substantially changed and become increasingly hetrogenious as traditional political parties and the ideological cleavages they represent are undermined by growing social fragmentation (for review of this litreature see Bennett, 2012). In many respects this characterisation of sociteal change is not disimilar to that described by Putnam (2000) and others above. However, where he and others see the decline of 'duty norms' as a problem, this perspective is more ambivilent about the normative effect of this shift and instead focuses on other ways that new forms of representation are occuring. Indeed, as Bennett $(2012, \mathrm{p} 33)$ outlines, some see this move as a positive challenge to the existing order and its entrenched political classes.

A more recent example of this perspective than the new social movements litreature can be found in the work of Henrik Bang (2005, 2011; Bang and Esmark, 2009). Bang distinguishes between an input view of representation where politicians turn conflict into meaningful consensus - the 'politics-policy' mode - and representation on an issue-by-issue basis - the 'policy-politics' mode (for review see Marsh, 2011a). In Bang's model, late modernity increaingly requires politicians to 'advocate' on behalf of policy proposals that have been crafted by 'expert citizens', thus fundamentally altering their traditional role which was to ensure that the views of citizens were taken into account during the policy-making process. Consequently, he argues that the main problem with the old input models of representation is that they do not acknowledged the far more positive role that politicians undertake on the output side of politics. And, if we understood the dynamics of this form of representation better we would be less inclined to demonise politicians. 
The related 'celebrity politics' literature (see Marsh et al., 2010; Marsh and Fawcett, 2011), makes a similar case. Marsh et al (2010, p 327), for example, differentiate between three types of 'celebrity politics' that relate to politicians: celebrities who become politicians, politicians who become celebrities, and the politician who uses others' celebrity for political ends. Such politicians, they argue, reflect the new media age and consumer culture of late modernity; they 'advocate' on behalf of certain 'brands' (personal, commercial and party) that sell 'products' (personalities and policies). And, by seeking to differentiate themselves from the stigma associated traditional politicians, such representatives are often powerful critics of input side politics in some cases they come to 'represent' appeals to anti-politics and increasing depoliticization.

By seeking to better describe the changing nature of representation much of this work - and this is particularly true of Bang - emphasises the transformative capacity of a politics of truth to replace neo-liberalism's politics of threats (as embodied by the principle-agent model). That is, if we better understood politicians' function in late modernity, and were able to encourage them to be honest about the limits of their role(s), we - the academy - could provide the people with a new vision of political authority tied to the acceptance of difference:

If we want to critique neoliberalism's politics of threats, we need begin from the presumption that political authority is analytically distinct from legitimacy, coercion, hierarchy and domination and that it has a creative potential for establishing a viable and balanced political relationship between political authorities and laypeople based on nothing but their mutual acceptance and recognition of each other's difference (Bang, 2011, p. 435). 
But, do the public want the truth? Ontological questions aside, and even if we could agree on the appropriate norms that encourage truth-telling, does the public really want their politicians to be honest brokers? Hibbing and Theiss-Morse (2002) argue that, above everything else, people do not like being taken for fools by their political leaders. But, does this mean we would prefer to be told that policy-making is, to borrow Weber's (1978 [1919]) famous phrase, 'a strong and slow boring of hard boards'? Do we want to believe that compromise is important and that governments only have limited capacity to improve our lives? Can we, to use Colonel Jessep's now clichéd line from A Few Good Men, handle the truth?

\section{The Thespian}

Since antiquity, politics has been associated with performance, the art of rhetoric and persuasion. This is not irreconcilable with the image of an advocate discussed above, but it does consider truth-telling in a fundamentally different light by illustrating, and even celebrating, the fact that politics is a form of vaudeville that is primarily concerned with constructing the truth. Politicians, from this perspective, are acting out a role that we may not like but we do need; and at the end of the day while we may not like who they are or the way they operate, the system does not work without them. Maarten Hajer's (2010) book Authoritative Governance employs terms like 'performative habitus' and 'networked dramaturgy', and metaphors like 'staging', 'setting' and 'scripting', to describe how political leaders manufacture authority in the new era of networked governance. Authority, for Hajer, has a fundamentally communicative quality and is therefore not given, but must be constantly (re)enacted, usually through the media. Like the work on celebrity politics, politicians are political personalities: 'frantically searching for ways to appeal to their public' (Hajer, 2010, p. 4). But, where this is seen by some as a new phenomenon, and as a problem for those who hark back to a lost golden age of honourable stewardship, for Hajer no such period existed. 
Rather, politics has always been about performance, with the main change being that, due to fragmented meanings and a multiplicity of actors and arenas, the new era of networked governance has made acting out the script more complex.

The familiarity of popular disenchantment with political leaders is also a theme in David Runciman's (2008, p. 196) book Political Hypocrisy in which he argues that there is no easy solution to the problem of 'deceitful and dissembling' politicians, as we require them to act out competing performances - to wear masks. From this perspective, if contemporary politicians are failing it is because they are unconvincing liars, there is no shared repertoire, and society has become obsessed with conspiracies and uncovering the 'truth'. For Runciman (2008, p. 196), it is only by recognising the essential familiarity of popular disillusionment that we can begin to appreciate the misplaced nature of much of this sentiment is.

Others, like Barry Hindess' (1996, 1997, 2001), see demonisation as fundamentally linked to popular concern with corruption, rather than, for example, disenchantment directed at endless factionalism. In particular, he contends that anti-politics is symptomatic of an idealised vision of the public sphere that has been invaded by private interests and concerns - begetting tyranny:

... most if not all contemporary understandings of politics could be seen as derived from idealised representations of the public life of the cities of classical antiquity. As a result, they are commonly infected by concerns over the boundaries between the political and the non-political - and in particular by the fear that politics will be corrupted through the intrusion of extraneous elements and that politics itself will tend to corrupt other aspects of the life of the community (Hindess, 1996, p. 36).

The performance of politicians, from this perspective, is increasingly measured against this ideal standard which has deep roots in the liberal tradition (Hindess 1996, p. 33). The 
problem for those who seek to uphold this tradition is that if we acknowledge that performance is relative and context specific, and thus relax our devotion to the ideal, the question then becomes not whether our politicians are corrupt, but how corrupt do we want them to be?

Finally, the naive repetitiveness of calls for better political leaders is also a feature of Kane and Patapan's (2012) recent book Democratic Leadership in which they argue that the tension between leadership and the democratic principle of popular sovereignty, where all people are equal, is at the heart of the 'problem' we have with our politicians. It is a problem, they claim, that cannot be solved. Rather, we must reconcile ourselves with the perpetual negotiation between leaders and followers required by democratic government - they see this tension as central to its dynamism and energy rather than undermining it. Like many of the authors discussed here, Kane and Patapan believe the academy has an important role to play in increasing public awareness about the conflicting demands that popular sovereignty places on democratic leaders in the belief that sympathetic appreciation can temper demonization.

\section{The Demonisation of Politicians: Future Research}

Having outlined how different strands of the anti-politics literature incorporate why we need politicians into their analysis, let me conclude with a brief discussion of what this typology asks us to do differently. Firstly, however, it is important to note that in many respects one thing that almost all of these scholars agree on is that taking this discussion outside of the academy and into the broader public domain is, as Crick exemplifies, the more pressing task, and I note with admiration that most of the authors discussed here have explicitly sought to emulate this aspect of his work. If, however, we take this need as a given, what other important questions emerge from this review? 
Conceptually, the typology captures the diversity of views on the normative purpose of politicians that points us towards the different definitions of politics that underpin each account. Clarifying what these definitions are and how they shape the way we see the problem and solution when it comes to anti-political sentiment is an important next step; Stoker is on the right track here with his title Why Politics Matters. That is, if we accept that we need to revive public faith in authority figures we also need to know who they are, what we want them to be like and how they should conduct themselves. Such debates are often ignored because they are either too complicated or have no satisfactory conclusion, or because it is hard to find something new to say. However, it is precisely because of their thorniness that we must continuously revisit them. As this typology demonstrates, descriptive and normative accounts of why we need politicians vary widely according to the views each of us holds about how we ought to be governed. Yet, despite this diversity, or perhaps because of it, populist negativity towards politicians as a group persists. As such, what this typology hints at, and what I suspect further conceptual work will reveal, is that there is no consensus around these questions and, in part, this plurality is at the heart of popular disillusionment; we might not be able to reach consensus on what politicians should be doing but we can at least agree that they are not doing what we want them to. In essence, this points us in the direction of the 'democratic leadership paradox' that Kane and Patapan (2012) describe.

The typology also highlights several empirical questions. From a critical perspective, there is already a burgeoning group of scholars interested in deliberative and participatory democracy, with a considerable research agenda underway (for review see Thompson, 2008; Leighninger, 2012). Obviously, this research is important, but there are other aspects of this debate that need to be considered. Let me briefly outline three. 
Firstly, while all of these authors provide explicit or implicit answers as to why politicians are demonised and what we can do about it, the voices of politicians themselves are largely absent from this debate. Consequently, and here I agree with Hay (2007, p. 162), given the pervasiveness of demonisation, we need to know more about what motivates people to run for public office. In addition, what is it like for those who do get elected? What influences their decisions and how do they reconcile competing expectations and roles? There is a body of work that investigates political life from a politician's perspective (for review see [omitted]), but it is relatively small. The main exception is the genre of political biography and autobiography. However, by and large, this extensive and enormously popular literature is ignored in contemporary debates (Rhodes, 2012; Arklay et al., 2006). This is a sad, and ultimately detrimental, disciplinary oversight, as life history writing can, despite its shortcomings, provide important insights into the human dimension of political life while greater appreciation of how real people navigate political roles can serve to temper popular dissatisfaction.

Secondly, each of these literatures has answers to the question of what is new about contemporary anti-politics but less to say about what is constant (Hogan 2007 is an exception). People didn't like politics in the past and, outside of Anglo-European democracies, politicians are similarly associated with vice. The Thespian literature provides some insights here by pointing us towards paradoxes and inherent contradictions contained within ideas like democratic leadership. As Kane and Patapan (2012, p. 165) show, Abraham Lincoln was vilified in his lifetime in much the same way that politicians are today even though he is now immortalised as one of democracies greatest heroes. Half a century ago, Crick's Defence had an eye on the dangers of nationalism and totalitarianism in particular. Here, we have been more concerned with elite capture, professional politicians, democratic 
decadents and neo-liberalism. In either case, we need to better understand the history of antipolitics, as a term and an idea.

Finally, truth-telling is a theme that runs through nearly all of these accounts. Ontological and epistemological questions aside, we all largely agree that politicians do not always tell the truth. In certain circumstances, as the Thespian section highlights, we also do not want politicians to tell us the truth, but, for the most part, we consider public trust to be a fundamental feature of democratic government, even if this trust is generated by 'performance', rather than 'authentic' representation. There is no shortage of material on when and how politicians lie - news services thrive on such scandals - just as there is an abundance of scholarship that prescribes one version or another of an appropriate instrumental response. Perversely, and here I am in broad agreement with Flinders' (2012b, p. 12) and Bang's (2011) emphasis on honesty, there is less interest in what happens when politicians tell the truth. But, if truth-telling is what we want to encourage, surely understanding what happens when politicians do tell the truth, or at least claim to tell the truth, is vital to how we conceptualise anti-politics and frame our response?

\section{Conclusion}

In this article I have reviewed the critical literature on anti-politics and the demonisation of politicians. In doing so I examined the implicit rationale for why we need politicians that each of these literatures offers - identifying six in particular: procedural, legitimacy, values, authority, persuasion and dissimulation. While I found that there is significant disagreement about what the appropriate role of politicians is, and should be, there are also features of this debate that we largely agree upon. In particular, I highlighted a general belief that if the public better understood political practice they would be less inclined to demonise those involved. Aside from being an important research question, I argued that this conviction 
points us towards several important avenues for future inquiry, including 1) the revival of age-old questions about the purpose of politics; 2) investigation of the views and experiences of political actors about their job; 3) the history of anti-politics as a term and an idea; and 4) an examination of what happens when politicians tell the truth. This list is obviously not exhaustive, but in framing possible areas for new research it is my hope that other scholars will take up the same question that I have sketched an answer to here and ask: but why do we need politicians? 


\section{Bibliography}

Ascher, I. 2013. 'We Are All Occasional Politicians': For a New Weberian Conception of Politics. Constellations 20(1), 138-149.

Arklay, T., Nethercote, J. and Wanna, J. (eds)., 2006. Australian Political Lives, Canberra: ANU E Press.

Bang, H., 2005 'Among everyday makers and expert citizens', in J. Newman (ed) Remaking governance: peoples, politics and the public sphere. Great Britain: The Polity Press, pp. 159-178.

Bang, H. and Esmark, A., 2009. 'Good governance in network society: reconfiguring the political from politics to policy', Administrative Theory \& Praxis, 31(1), 7-37.

Bang, H. P., 2011. 'The politics of threats: late-modern politics in the shadow of neoliberalism', Critical policy studies, 5(4), 434-448.

Bennett, W. L., 2012. 'The Personalization of Politics Political Identity, Social Media, and Changing Patterns of Participation', The Annals of the American Academy of Political and Social Science, 644, 20-39.

Cohen, J., 1989, 'Deliberation and democratic legitimacy', Debates in Contemporary Political Philosophy, 342.

Cohen, J., 1997. 'Procedure and substance in deliberative democracy', Deliberative Democracy: Essays on Reason and Politics, Cambridge: MIT Press, pp. 407-437.

Crick, B., 2000 [1962]. In Defence of Politics, Great Britain: Continuum.

Dionne, E., 2004. Why Americans hate politics, New York: Simon and Schuster.

Dunleavy, P. and Rhodes, R. A., 1990. 'Core executive studies in Britain', Public Administration, 68(1), 3-28.

Elgie, R., 1995. Political Leadership in Liberal Democracies, New York: St. Martin's Press.

Elgie, R., 2011. 'Core executive studies two decades on', Public Administration, 89(1), 64-77.

Evans, M., Stoker, G., \& Nasir, J. (2013). How do Australians imagine their democracy? Australian survey of political engagement findings 2013. Canberra, Australia: Australian and New Zealand School of Government. http://www.governanceinstitute.edu.au/magma/media/upload/ckeditor/files/DEMOCRACY\% 20REPORT-\%20UPDATED\%20VERSION-27-6-13.pdf (accessed 19/11/2013)

Fawcett, P. and Marsh, D. (forthcoming) 'Depoliticization, Governance and Political Participation'.

Flinders, M., 2012a. Defending Politics: Why Democracy Matters in the Twenty-First Century, Oxford and New York: Oxford University Press.

Flinders, M., 2012b. 'The demonisation of politicians: moral panics, folk devils and MPs' expenses', Contemporary Politics, 18(1), 1-17.

Fung, A., 2004. Empowered participation: reinventing urban democracy, Princeton: Princeton University Press.

Gutmann, A. and Thompson, D., 2004. Why deliberative democracy?, Princeton: Princeton University Press.

Hajer, M. A., 2010. Authoritative governance: policy making in the age of mediatization, Oxford: Oxford University Press.

Hatier, C. 2012. 'Them' and 'us': demonising politicians by moral double standards. Contemporary Politics, 18(4), 467-480.

Hay, C., 2007. Why We Hate Politics, Cambridge: Polity Press.

Hay, C. and Stoker, G., 2009. 'Revitalising Politics: Have We lost the Plot?', Representation, 45(3), 225-236.

Heffernan, R., 2003. 'Prime ministerial predominance? Core executive politics in the UK', The British Journal of Politics \& International Relations, 5(3), 347-372. 
Hibbing, J. R. and Theiss-Morse, E., 2002. Stealth democracy: Americans' beliefs about how government should work, Cambridge University Press.

Hindess, B., 1996. 'Fears of Intrusion: Anti-Political Motifs in Western Political Discourse', in A. Schedler (ed) The End of Politics. Great Britian: Macmillan Press Ltd, pp. 2139.

Hindess, B., 1997. 'Democracy and Disenchantment', Australian Journal of Political Science, 32(1), 79-82.

Hindess, B., 2001. 'Democracy as Anti-Democracy', Southern Review, 34(1), 9-21.

Jessop, B., 2004. 'Multi-level Governance and Meta-governance: on Reflexivity, Requiste Variety and Requisite Irony', in H. Bang (ed) Governance as Social and Political Communication. Manchester: Manchester University Press.

Hogan, M. 2007. Anti-political sentiment in contemporary liberal democracies. Australian Review of Public Affairs, 8(1), 1-18.

Jones, K., 2008. 'Professional Politicians as the Subjects of Moral Panic', Australian Journal of Political Science, 43(2), 243-258.

Kane, J. and Patapan, H., 2012. The Democratic Leader: How Democracy Defines, Empowers, \& Limits its Leaders, Oxford: Oxford University Press.

Keane, J., 2009. The Life and Death of Democracy, London, New York, Sydney and Toronto: Simon and Schuster.

Leighninger, M., 2012. 'Mapping Deliberative Civic Engagement: Pictures from a (R)evolution', in T. Nabatchi, J. Gastil, M. Leighninger and G. M. Weiksner (eds) Democracy in motion: Evaluating the practice and impact of deliberative civic engagement. Oxford and New York: Oxford University Press, pp. 19-42.

Marsh, D., 2011a. 'Late modernity and the changing nature of politics: two cheers for Henrik Bang', Critical policy studies, 5(1), 73-89.

Marsh, D., 2011b. 'The new orthodoxy: the differentiated polity model', Public Administration, 89(1), 32-48.

Marsh, D. and Fawcett, P., 2011. 'Branding, politics and democracy', Policy Studies, 32(5), 515-530.

Marsh, D., Richards, D. and Smith, M., 2003. 'Unequal plurality: towards an asymmetric power model of British politics', Government and Opposition, 38(3), 306-332.

Marsh, D., t Hart, P. and Tindall, K., 2010. 'Celebrity politics: The politics of the late modernity?', Political Studies Review, 8(3), 322-340.

McAnulla, S., 2006. 'Challenging the new interpretivist approach: Towards a critical realist alternative', British Politics, 1(1), 113-138.

Norris, P., 2011. Democratic Deficit: Critical Citizens Revisited, Cambridge: Cambridge University Press.

Putnam, R. D., 2000. Bowling alone: the collapse and revival of American community, New York, Simon \& Schuster.

Rhodes, R. A. W., 1997. Understanding governance: policy networks, governance, reflexivity, and accountability, Buckingham and Philadephia, Open University Press.

Rhodes, R. A. W., 2007. 'Understanding Governance: Ten Years On', Organisation Studies, $28,1243-1264$.

Rhodes, R. A. W., 2012. 'Theory, Method and British Political Life History', Political Studies Review, 10(2), 161-176.

Rhodes, R. A. W. and Bevir, M., 2010. The State as Cultural Practice, Oxford and New York: Oxford University Press.

Riddell, P., 2010. 'In Defence of Politicians: In Spite of Themselves', Parliamentary Affairs, 63(3), 545-557. 
Runciman, D., 2008. Political Hypocrisy : The Mask of Power, from Hobbes to Orwell and Beyond, Princeton: Princeton University Press.

Sørensen, E., 2006. 'Metagovernance The Changing Role of Politicians in Processes of Democratic Governance', The American Review of Public Administration, 36(1), 98114.

Stoker, G., 2006. Why Politics Matters: Making Democracy Work, Houndmills [England]; New York: Palgrave Macmillan.

Thompson, D. F., 2008. 'Deliberative democratic theory and empirical political science', Annu. Rev. Polit. Sci., 11, 497-520.

Torcal, M. and Montero, J. R. (eds)., 2006, Political Disaffection in Contemporary Democracies: Social capital, institutions, and politics, New York: Routledge.

Uhr, J., 1998. Deliberative democracy in Australia, Cambridge University Press.

Weber, M., 1978 [1919]. Politics as a Vocation. in W. G. Runciman (ed) Max Weber: Selections in Translation. Combridge: Cambridge University Press.

Weber, M. 1978 [1922]. Economy and Society. California: University of California Press.

Wood, M., \& Flinders, M. 2012. From Folk Devils to Folk Heroes: Rethinking the Theory of Moral Panics. Moral Panic Studies Working Paper Series, 2012/2: http://www.brunel.ac.uk/_data/assets/pdf_file/0009/255339/20122FromFolkDevilsto FolkHeroesWoodandFlinders.pdf (accessed 21/11/2013). 